\title{
IMPROVED METRICS FOR WORKPLACE DISPUTE RESOLUTION PROCEDURES: EFFICIENCY, EQUITY, AND VOICE
}

\author{
John W. Budd \\ Industrial Relations Center \\ University of Minnesota \\ 3-300 Carlson School of Management \\ Minneapolis, MN 55455-0438 \\ jbudd@ @csom.umn.edu \\ (612) 624-0357 \\ fax: (612) 624-8360
}

\author{
Alexander J.S. Colvin \\ Dept. of Labor Studies and Employment Relations \\ Penn State University \\ 124 Willard Building \\ University Park, PA 16802-2800 \\ ajc10@psu.edu \\ (814) 865-0754 \\ fax: (814) $863-3578$
}

Final Version Date: July 30, 2007

We are grateful to Mike Bognanno and Hoyt Wheeler for their helpful comments on an earlier draft of this paper. 


\title{
IMPROVED METRICS FOR WORKPLACE DISPUTE RESOLUTION PROCEDURES: EFFICIENCY, EQUITY, AND VOICE
}

\begin{abstract}
$\underline{\text { Abstract }}$
Many debates surround systems for resolving workplace disputes. In the United States, traditional unionized grievance procedures, emerging nonunion dispute resolution systems, and the court-based system for resolving employment law disputes have all been criticized. What is missing from these debates are rich metrics beyond speed and satisfaction for comparing and evaluating dispute resolutions systems. In this paper, we develop efficiency, equity, and voice as these standards. Unionized, nonunion, and employment law procedures are then qualitatively evaluated against these three metrics.
\end{abstract}


The design and operation of workplace dispute resolution systems are longstanding issues in human resources and industrial relations. But what are the metrics for evaluating workplace dispute resolution systems? For human resource managers to design effective dispute resolutions systems, for union leaders to advocate certain systems, for policymakers to promote or restrict various systems, and for researchers to know what to analyze we must identify the important dimensions for comparing dispute resolution systems. There is rich theoretical and empirical research on workplace dispute resolution that has significantly advanced our understanding of many issues, but what's missing is a common set of metrics for evaluating and comparing workplace dispute resolution procedures (Bemmels and Foley 1996; Lewin 1999; Lipsky, Seeber, and Fincher 2003; Olson-Buchanan and Boswell, 2007).

To this end, then, we extend Budd's (2004) analyses of the objectives of the employment relationship and assert that the metrics for evaluating and comparing systems of dispute resolution are efficiency, equity, and voice. This analytical framework applies to dispute resolution systems in a wide variety of contexts - disagreements over employment conditions, workplace rights, legal rights outside of the workplace, marital dissolution, and global trade agreements, for example. As a first application, this paper focuses on workplace rights disputes. ${ }^{1}$

\section{The Lack of Good Dispute Resolution Metrics}

Among dispute resolution mechanisms for workplace rights disputes, unionized grievance procedures have been researched to the greatest extent. Studies have analyzed the determinants of grievance initiation (Bemmels 1994; Bacharach and Bamberger 2004), attitudes towards and satisfaction with grievance procedures (Bemmels 1995; Bemmels and Lau 2001), grievance processing speed (Lewin and Peterson 1988; Ponak, et al. 1996), the determinants of grievance outcomes (Meyer and Cooke 1988; Klaas 1989), the relationship between grievance 
activity and individual and organizational performance (Kleiner, Nickelsburg, and Pilarski 1995; Lewin and Peterson 1999; Boswell and Olson-Buchanan 2004), and a host of other related issues. And yet there is a lack of accepted metrics for evaluating grievance procedures.

The two primary measures used to date for assessing grievance procedures are speed and satisfaction. The speed literature typically analyzes how long it takes to resolve grievances and at what step of the process grievances are resolved. The satisfaction literature typically surveys parties to the grievance procedure to measure their perceptions of grievance procedure effectiveness. At best, these are imperfect and incomplete measures of grievance procedure effectiveness. By itself, how quickly a dispute is resolved tells us very little about the effectiveness of the resolution (Bemmels and Foley 1996; Lewin 1999). In fact, empirical research finds that the speed of a resolution is not related to satisfaction with and attitudes towards grievance procedures (Clark and Gallagher 1988; Gordon and Bowlby 1988). Satisfaction has also been shown to be confounded by a host of other factors such as union satisfaction, union commitment, employer commitment, and dual commitment (Fryxell and Gordon 1989; Bemmels 1995). As such, Bemmels and Foley (1996: 375) conclude that "effectiveness is difficult to interpret from measures reflecting the operation of grievance procedures" while Lewin (1999: 154) concludes that "there is a lack of consensus among researchers about what exactly constitutes grievance procedure effectiveness.”

These conclusions - and implicit calls to action — apply equally well to nonunion workplace dispute resolution procedures. As just one example of the imperfect metrics in this domain, research on the due process elements of nonunion procedures is quite limited (Feuille and Chachere 1995; Colvin 2003a, 2003b). The lack of good metrics within areas of workplace dispute resolution research means a lack of metrics for undertaking comparative analyses across 
different procedures. In fact, Lewin (1999: 158) criticizes the research on unionized grievance procedures because it has "failed adequately to consider the effectiveness of grievance procedures in relation to the effectiveness of other forms of workplace conflict resolution." So there is a clear need to identify and develop critical dimensions that can be compared across all types of workplace dispute resolution procedures.

\section{Efficiency, Equity, and Voice}

Budd (2004) argues that the objectives of the employment relationship are efficiency, equity, and voice. Efficiency is the effective, profit-maximizing use of scarce resources and captures concerns with productivity, competitiveness, and economic prosperity. Equity entails fairness in both the distribution of economic rewards and the administration of employment policies. Voice is the ability of employees to have meaningful input into workplace decisions both individually and collectively. Efficiency is a standard of economic or business performance; equity is a standard of treatment; voice is a standard of employee participation. Budd (2004) further analyzes alternatives for workplace governance, union strategies, and comparative industrial relations systems against the standards of efficiency, equity, and voice. Applying this framework to dispute resolution procedures provides a rich analytical framework in which researchers, practitioners, and policymakers can analyze and compare dispute resolution systems along the dimensions of efficiency, equity, and voice. ${ }^{2}$ To this end, we first define efficiency, equity, and voice in the context of dispute resolution procedures. The remaining sections of the paper qualitatively analyze unionized, nonunion, and employment law dispute resolution procedures for resolving rights disputes against these standards.

An efficient dispute resolution system is one that conserves scarce resources, especially time and money. Systems that are slow and take a long time to produce a resolution are 
inefficient; systems with shorter timeframes that produce a relatively quick resolution are efficient. Similarly, dispute resolutions systems that are costly are inefficient. Costs can stem from various features of a dispute resolution system such as the need for high-paid experts or the involvement of numerous participants. ${ }^{3}$ For workplace dispute resolution systems, another aspect of efficiency is the extent to which the system fosters productive employment. Preventing strikes or providing unconstrained managerial decision-making are elements of dispute resolution systems that promote this aspect of efficiency. Costs might also be non-financial—disputants may suffer psychological costs and disrupted social relations. These non-financial costs may, in turn, negatively affect organizational efficiency and individual careers.

Equity in the context of dispute resolution systems is a standard of fairness and unbiased decision-making. Outcomes in an equitable system are consistent with the judgment of a reasonable person who does not have a vested interest in either side, and are supported by objective evidence. Equity also requires that the outcomes provide effective remedies when rights are violated. Individuals in similar circumstances should receive similar treatment and face similar, though not necessarily identical, resolutions. Moreover, an equitable system treats the individual participants with respect, sensitivity, and privacy. Equity also includes the existence of safeguards - such as the ability to appeal decisions to a neutral party-and transparency to prevent arbitrary or capricious decision-making and enhance accountability. An equitable dispute resolution system also has widespread coverage independent of resources or expertise and is equally accessible irrespective of gender, race, national origin, or other personal characteristics.

The voice dimension of dispute resolution systems captures the extent to which individuals are able to participate in the operation of the dispute resolution system. This dimension includes important aspects of due process such as having a hearing, presenting 
evidence in one's defense, and being assisted by an advocate if desired. Voice can also include the extent to which individuals have input into the construction of the dispute resolution system and into specific resolutions. As equity and voice might both be casually described as fairness or justice, it can be tempting to combine the two dimensions. But equity and voice are different and require separate analyses. The equity dimension focuses on outcomes whereas the voice dimension focuses on participation in the process. A dispute resolution system can be equitable (by producing unbiased outcomes) but lack voice, or can include voice but be inequitable. For example, a system in which a neutral, just decision-maker decides disputes unilaterally could have a significant measure of equity, but lack voice. This distinction becomes particularly important in analyzing dispute resolution systems in nonunion workplaces where the question arises of how to categorize the benevolent paternalistic employer who treats employees very well, yet retains strong control over the process and outcome of any complaints or disputes.

An alternative approach for comparing workplace dispute resolution systems is to use distributive and procedural justice. Efficiency, however, is not well captured in the distributive and procedural justice framework, yet is an important consideration in evaluating the functioning of a dispute resolution system. Moreover, distributive and procedural justice focus on how individuals are treated in terms of outcomes and process. In our framework, equity captures how people are treated (outcome-wise and procedurally), voice captures participation. In a procedural justice framework, individuals participate to the extent that this promotes fairness. In a voice framework, individuals participate because participation is intrinsically important, regardless of whether it is fair or not. In some models of procedural justice, procedural justice can be achieved unilaterally. This is never the case with voice. 
The metrics of efficiency, equity, and voice provide an analytical framework for analyzing and comparing different dispute resolution systems. Following Hyman's (2001) "geometry of trade unionism" and Budd's (2004) "geometry of the employment relationship", this analysis yields the "geometry of dispute resolution procedures."4 As such, the baseline union, nonunion, and employment law dispute resolution systems are located in Figure 1 based on the extent to which they are efficient, equitable, and provide voice. These relative locations will become apparent as the various procedures are discussed in the remainder of the paper. Disagreements over these locations are welcomed as the major contribution of this threedimensional framework is providing the coherent basis for such debates.

Figure 1 is intended as a convenient tool for considering and comparing various systems of dispute resolution. We recognize that more precise analyses require identifying and measuring specific components of efficiency, equity, and voice. Table 1 therefore provides an initial decomposition of the three metrics with some suggested measures. Recent research on workplace dispute resolution has examined a number of these measures as important indicators of the performance of procedures. For example, comparisons of employment arbitration and litigation have examined speed, cost and award outcomes as indicators of the relative efficiency and equity advantages of these procedures (Delikat and Kleiner 2003; Eisenberg and Hill 2003). Other research examining employment arbitration has investigated biases in decision-making (Bingham 1997) and consistency of outcomes (Bingham and Mesch 2000; Wheeler, Klaas, and Mahony 2004; Klaas, Mahony, and Wheeler 2006) as important equity indicators. In constructing a due process index to compare nonunion grievance procedures, Feuille and Chachere (1995) included equity measures, such as the independence of the decision-maker, and voice measures, such as the ability to have representation at hearings. Comparing outcomes of 
nonunion grievance procedures, Colvin (2003b) used voice and equity measures including the rate of appeals and employee success rates. Each of these studies, and other similar ones, indicate the value of these specific measures, which capture aspects of the broader metrics of efficiency, equity, and voice. Previous studies, however, have not combined individual measures into broad metrics and an overall theoretical framework for comparing and evaluating workplace dispute resolution procedures. The remainder of this paper focuses on a qualitative analysis of efficiency, equity, and voice; further development of specific quantitative measures is left to future research.

\section{Unionized Workplace Procedures}

The dominant dispute resolution system in U.S. unionized workplaces is a formal grievance procedure with binding arbitration. However, in response to concerns with the cost, timeliness, and quasi-legal nature of grievance arbitration, the unionized sector is also experimenting with expedited arbitration and grievance mediation systems (Feuille 1999; Colvin, Klaas, and Mahony 2006). All three systems can be usefully analyzed against the metrics of efficiency, equity, and voice.

\section{Grievance Arbitration}

Grievance arbitration, or rights arbitration, involves a hearing before a third-party neutral (the arbitrator) over a dispute over a provision of a union contract; the arbitrator's subsequent binding ruling resolves the dispute. Relative to court proceedings in the U.S. legal system or to strikes, the grievance arbitration dispute resolution system is efficient (Zack and Dunlop 1997). It is less costly than both of these options and can also enhance productive efficiency by preventing work stoppages and by identifying areas of conflict. But relative to less formal procedures, grievance arbitration is criticized for being lengthy (perhaps a year from grievance filing to arbitrator decision) and costly (perhaps $\$ 10,000$ or more per hearing) (Feuille 1999). 
The quasi-judicial nature of grievance arbitration with a strong reliance on past precedents can also be criticized for inhibiting flexibility and change. This system is also reactive and backward looking to determine guilt or innocence rather than forward looking and proactive to solve problems (Lewin 2005). As such, there are efficiency concerns with grievance arbitration.

Grievance arbitration is evaluated highly on the equity dimension. The threat of a binding decision by an outsider provides labor and management with the incentive to settle grievances fairly and respect due process throughout the process (Zack and Dunlop 1997). Formal hearings and reliance on credible, objective evidence are central features of the U.S. grievance arbitration system. The binding decisions by neutral arbitrators provide effective mechanisms for remedying unfair treatment in the workplace. Workers found to be fired without just cause, for example, are reinstated with back pay. Moreover, these decisions commonly rely heavily on past arbitration precedents and past workplace practices. As a result, there is a high degree of consistency in decision-making across cases so workers who have similar grievances in similar circumstances receive similar treatment. This consistency is an important component of equity.

With respect to voice, the evaluation of grievance arbitration is mixed. As grievance arbitration systems are negotiated rather than imposed, labor and management have a high degree of voice in establishing the process (Zack and Dunlop 1997). Moreover, both sides participate equally in all steps of unionized grievance procedures and the various parties are represented by attorneys or other advocates as desired in arbitration proceedings. There are strong traditions of fulfilling basic due process rights such as being heard and presenting evidence. On the other hand, the bureaucratic nature of traditional grievance procedures and the importance of stewards, union officials, and attorneys rather than individual workers is attacked by critical scholars for stifling rank and file involvement and voice (Stone 1981; Klare 1988). 
Though partly mitigated by the duty of fair representation, union carriage of grievances may also reduce employee voice when the interests of the union and the individual grievant differ. Lastly, voice is stronger in the process than in the outcome because a third party (an arbitrator) unilaterally imposes the final resolution to the dispute (though the parties have control over the outcome at the lower stages of the grievance procedure).

\section{Expedited Arbitration and Grievance Mediation Alternatives}

Efficiency concerns underlie experimentation with expedited arbitration and grievance mediation alternatives to grievance arbitration. Expedited arbitration reduces costs and fosters faster resolution of grievances by avoiding written briefs, transcripts, perhaps lawyers, and detailed, written decisions. Abbreviated hearings, reduced reliance on precedent, and a more limited opportunity to present grievances, however, might reduce equity and voice. Alternatively, the inclusion of a grievance mediation step before arbitration can also help avoid arbitration and its associated delays, costs, and legal formalities. Relative to an arbitration-only process, there is the possibility that equity suffers because of a reduced role of neutral labor arbitrators in ensuring consistency across grievances, but since the parties retain control of the resolution in mediation, any inconsistencies are agreed to by the parties. Moreover, the parties retain the right to pursue arbitration when mediation fails to provide a satisfactory resolution. With respect to voice, grievance mediation enhances voice because the parties are agreeing to a negotiated settlement of the dispute.

\section{Nonunion Workplace Procedures}

While nonunion grievance procedures may lack the highly developed institutionalized structure of union grievance procedures, they cover a much larger segment of the overall workforce and are an increasingly important mechanism for regulating workplace conflict. As a 
result, it is important to examine the relative advantages and disadvantages of the different types of nonunion grievance procedures. The metrics of efficiency, equity, and voice provide a useful way for comparing unionized dispute resolution systems with nonunion systems, and also for comparing the various nonunion alternatives with each other.

\section{Unilateral Management Discretion and Open Door Policies}

In the absence of a formal dispute resolution procedure, the response to employee complaints is left to unilateral management discretion. This situation clearly strongly favors efficiency by providing for quick and cheap resolutions and promotes productive efficiency by allowing unconstrained management decision making. The equity dimension is weaker as fair treatment depends on managerial roles, values, attitudes, and personal senses of fairness and is therefore uncertain and highly variable (Karambayya and Brett 1989; Colvin 2001). There is no hearing at which evidence is formally presented nor is there a neutral decision-maker to consider the positions of each side and render an adjudication of the dispute. With respect to voice, employees are essentially supplicants, hoping to receive the favor of management in response to their request. Open door policies might also include: the ability of employees to bring complaints to a manager outside of the immediate chain of command; policies discouraging retaliation against employees who make complaints; and provisions to keep track of and follow-up on complaints. But the resolution of the employee's concern is still up to the initiative of the manager responding to the complaint (Colvin, Klaas, and Mahony, 2006). The result is a system that, in the geometry of dispute resolution, has very high efficiency and very low equity and employee voice. $^{5}$ 


\section{Management Appeal Procedures}

Whereas open door policies typically lack a formal structure for appealing grievances, more formal nonunion grievance procedures often include multi-step appeal procedures that superficially resemble the multi-step grievance procedures of unionized workplaces, but at each stage of the procedure, managers are the decision-makers. Employees also do not have independent representation, except perhaps the assistance of an HR staffperson (Feuille and Chachere 1995; Colvin 2004). Formal hearings with presentation of evidence, examination of witnesses and presentation of arguments are relatively rare (Feuille and Delaney 1992). These management appeal procedures involve some enhancement of equity relative to open door policies, especially through the formal structure of procedures and provision of specific steps for appealing unfavorable decisions (Colvin, Klaas, and Mahony, 2006). But retention of management control over decision-making under this type of procedure represents a major due process deficiency and weakness from the equity perspective (Colvin 2001). Grievance procedures with management decision-makers offer relatively little from an employee voice perspective. Control over the design, rules, and decision-making under this type of procedure are retained by management and lack employee voice. In addition, the lack of independent representation of employees under the vast majority of these procedures limits the extent of voice in the process of resolving grievances. Thus, the overall geometry of this type of procedure consists of some limited enhancement of equity relative to open door policies, little in the way of employee voice, and an emphasis on efficiency.

\section{Peer Review}

Under nonunion peer review procedures, employees sit on a panel that decides grievances (McCabe and Lewin 1992; Colvin 2003b, 2004). A typical panel might consist of two managers 
and three employees who are peers of the complainant, with the key characteristic being that the peer employees comprise a majority of the members of the panel. Peer review panels are often introduced as part of a union substitution strategy in order to provide employees with a stronger alternative to union grievance procedures than the typical nonunion procedures that use only management decision-makers (Colvin 2003a). In other words, peer review procedures shift the emphasis between efficiency, equity, and voice. Some efficiency is sacrificed due to the more elaborate hearing procedures, examination of witnesses, and documentary evidence. However, a key benefit of using a peer review panel from an equity perspective is the greater independence of the decision-makers from management (Colvin 2003b). Given that peer employees are a majority on the panel, they have the ability to overrule management decisions that they view as unfair. At the same time, it should also be recognized that management establishes the rules under which the panel operates, which may result in limitations from an equity perspective, such as if management includes a rule limiting the panel to deciding whether company policies were correctly applied, rather than allowing general considerations of fairness (Colvin 2004). Peer review procedures also include a stronger employee voice element than typical nonunion grievance procedures because employees can present their case to a panel.

\section{Ombudspersons}

An ombudsperson is a resource outside of ordinary organizational hierarchies for employees to bring complaints and problems and obtain assistance in resolving them (McCabe and Lewin 1992; Lipsky, Seeber, and Fincher 2003). Depending on the situation, the ombudsperson may play a role in resolving a dispute akin to that of a mediator or more in the role of an advocate for the employee. The cost of devoting specific personnel and resources to the ombudsperson's office represents a limitation of this type of procedure from an efficiency 
perspective (Lipsky, Seeber, and Fincher 2003). On the other hand, the ombudsperson may enhance efficiency by promoting more cooperative relations between employees within the organization (Reuben 2005). From an equity perspective, the strength of the ombudsperson is that they can get employee problems addressed by managers who would be less likely to respond to an employee acting on their own. However the lack of formal procedures and open hearings under an ombudsperson procedure also creates a lack of guarantees of equal treatment and uncertainty over the degree to which employee interests are protected From a voice perspective, an ombudsperson may help give employees a more effective voice in pursuing workplace complaints. At the same time, ombudspersons are employees of the organization and so the degree to which they represent a genuinely independent voice on behalf of employees seeking their assistance can be questioned (Colvin, Klaas, and Mahony 2006). Although both peer review and ombudsperson's offices may have deficiencies in the areas of equity and voice relative to union grievance procedures, they are noteworthy attempts to alter the geometry of dispute resolution in the nonunion workplace to increase the emphasis on equity and voice despite some cost in efficiency.

\section{Employment Law Procedures}

A special set of workplace rights disputes pertain to alleged violations of statutory employment laws or common law principles. In many countries, these employment law disputes are resolved through specialized labor courts or industrial tribunals that feature expert decisionmakers and simple, expedited procedures. In contrast, in the United States, claims of employment law violations are usually resolved through the general court system. This employment litigation system strongly emphasizes equity and provides for a strong, albeit relatively formal, structure for employee voice. But dispute resolution through jury trials courts 
is extremely expensive relative to other systems and raises concerns of both access to the system and waste of resources. Partly in reaction to these concerns, there has been growing efforts to use alternative dispute resolution procedures, including both mediation and arbitration, to resolve employment law disputes.

\section{Employment Law Litigation}

The great strength of the system of litigation in the courts is its strong focus on equity in resolving disputes. In order to ensure that all relevant information is considered in the decisionmaking process, extensive pre-trial procedures allow for discovery of written documents and deposition of witnesses (Reuben 2005). At the trial itself, both the employee and the employer are able to fully test the claims of the other side through presentation and cross-examination of witnesses. To enhance the fairness of the decision, a jury of twelve unbiased people is empowered to render a verdict on the claim, with an experienced judge present to resolve any questions of law. To further ensure equity in the process, any errors of law in the trial can be appealed to higher courts to be resolved by a panel of highly experienced judges. At the same time, employer-side complaints have been raised about the employment litigation system from an equity perspective. In particular, concerns have focused on the lack of consistency in awards and danger of large, "runaway" jury verdicts. Whereas equity may be commonly viewed as an employee-centered concern, employment litigation provides an example where employers have also advanced arguments that are framed around the metric of equity in evaluating a dispute resolution procedure.

The downside to the strong equity protections of the litigation system is the resulting limitations of the system from an efficiency perspective. While the elaborate pre-trial discovery procedures of litigation maximize the likelihood that all relevant information comes to light 
before trial, this also requires extensive time and effort and may involve sifting through large amounts of irrelevant or unimportant information. Resolving workplace rights disputes through the U.S. court system is anything but speedy (Eisenberg and Hill 2003). In addition to the direct costs to the parties of attorneys and expert witnesses, there are substantial costs borne by the public of providing judges and the lost productivity of citizen jurors who are required to be absent from their own jobs for the period of the trial.

From the perspective of voice, the litigation system has both strengths and weaknesses. A key strength is the ability of a plaintiff employee to obtain a full hearing of an employment law claim against an employer (Reuben 2005). The system, quite literally, ensures the employee will get their day in court and the opportunity to have their positions fully presented. At the same time, the complexity of legal rules requires that a professional attorney be retained to oversee and present the case. Complex legal rules can also often channel cases to focus on issues different from or in addition to the underlying interests that initially motivated the dispute. For example, an employee who is dismissed after many years of loyal service may be motivated to bring suit in order to give voice to feelings that the employer has violated the employee's trust, yet in litigation the case may need to be framed as an age discrimination case to provide a legal basis for the claim. Another voice aspect of the litigation system is provided by the jury, which serves as a voice of the community or the public. In particular, the ability to award punitive damages allows the jury to give voice to the view that an employer has engaged in conduct that far exceeds the boundaries of acceptable behavior. An additional voice aspect of the litigation system is that this is a public system in which the laws and rules governing the system are established through the democratic process (Reuben 2005). 
As with equity, some concerns with the litigation system have been raised from an employer-side perspective in the area of voice. In particular, criticisms of the American litigation system often raise the specter of out of control juries with little appreciation of the realities of operating a business awarding inflated damages to plaintiffs at the behest of money-seeking trial attorneys (Olson 1997). Although arguments can be presented as to the accuracy or lack thereof of this image, the key point to recognize is that the criticism is partly directed at a perceived lack of employer voice in the litigation system. This reinforces both the importance of considering the voice metric in evaluations of dispute resolution process and the need to recognize the existence of employer, as well as employee, considerations in the area of voice.

\section{Employment Law Arbitration}

The costs and inefficiencies of the litigation system have been a driving force in the increasing use of alternative dispute resolution procedures to resolve employment law disputes in the United States. Employment law arbitration holds significant potential advantages over litigation from an efficiency perspective. Rather than requiring a judge, twelve-person jury, and various court officers, arbitration typically occurs before a single arbitrator. Arbitration procedures are generally simpler and more expedited than litigation procedures. In particular, pre-trial discovery procedures are much less extensive in arbitration than in litigation. All of this serves to reduce the time and cost involved in bringing a claim through arbitration compared with litigation, creating greater efficiencies in the system (Estreicher 2001; Hill 2003). Whereas

State and Federal court cases take an average of around two years to adjudication, a sample of employment discrimination claims arbitrated under the auspices of the American Arbitration Association averaged only 276 days to adjudication (Eisenberg and Hill 2003). 
Employment law arbitration, however, can be strongly criticized from an equity perspective. The simplification of procedures in arbitration that enhances efficiency has been criticized as sacrificing equity through the elimination of due process protections (Stone 1996). In particular, the more limited pre-trial discovery procedures of arbitration may seriously limit the ability of plaintiff employees to gather information necessary to support their claims. This concern is heightened in employment law cases because much of the relevant information, such as personnel records and files or witnesses who are employees, is under the control of the employer. The use of professional arbitrators as decision-makers has also been criticized from an equity perspective as creating a danger that arbitrators will tend to be biased towards employers, who are likely to be repeat players in the system, over employees, who are more likely to be single-time players in the system (Bingham 1997). In fact, empirical research shows that employment arbitrators are significantly less likely to rule in favor of employee complainants than were comparison groups of labor arbitrators, peer review panelists, and jurors, though they may be more likely to favor employee complainants than managerial decision-makers in other nonunion procedures (Bingham and Mesch 2000; Colvin 2003b; Wheeler, Klaas, and Mahony 2004). Another concern with arbitrators as decision-makers is that they will be much less likely than juries to make large punitive damage awards to punish egregious employer misbehavior (Colvin 2001). On the other hand, some argue that employment arbitration may have an equity enhancing effect by lowering costs and thereby making it easier for employees to bring claims than with litigation (Estreicher 2001). More efficient and equitable outcomes might also result because compared to broadly-trained judges and inexperienced juries, employment law arbitrators can have specialized knowledge of employment law and a greater sensitivity towards 
the nature of the employment relationship and the standing of individual employees in the dispute resolution system (Estreicher 2001).

Issues of voice have received less attention in evaluations of employment arbitration. Voice is present in the ability of the employee participate in the selection of the arbitrator and to present their case. The main weakness of employment arbitration from the standpoint of voice is that the employer controls the development and adoption of the procedure (Colvin 2003a). In this respect, employment arbitration compares unfavorably with labor arbitration, where voice is provided by joint union and management negotiation of the contractual rules under which arbitration occurs. Lastly by shifting enforcement of public employment laws from the public forum of the courts to the private forum of arbitration, use of employment law arbitration may reduce the degree of voice provided through the democratic political process (Stone 1996).

\section{Employment Law Mediation}

Employment law mediation provides another alternative to litigation for resolving employment disputes. In mediation, a neutral mediator helps resolve the dispute by facilitating negotiation of a settlement between the parties (Lipsky, Seeber, and Fincher 2003). Employment law mediation increases efficiency relative to litigation and arbitration by encouraging quicker, less costly resolution of disputes (Bingham 2004). From the perspective of equity, mediation has the advantage that resolutions consist of consensual agreements between the employee and employer. As a result, the concerns about bias in decision-making that have been directed at employment arbitration are diminished with employment law mediation. From a voice perspective, employment law mediation has the advantage that the employee has a voice in both the process and result of dispute resolution (Reuben 2005). If the employee does not agree with the proposed settlement, they can simply decline to reach an agreement. However, it is of 
concern that some research suggests that in employment mediation occurring as a pre-arbitration step in employer-promulgated procedures, many employees do not have a representative, or only a non-attorney representative such as a family or community member or a fellow employee (Colvin 2004). The danger here is that employees without legal representation may not realize that they are giving up possible legal claims in a mediation settlement.

Although space limitations do not permit us to do so here, a similar analysis could be extended to other procedures that focus on facilitating settlements between the parties rather than providing a binding determination of the outcome of the dispute. For example, Early Neutral Evaluation and minitrials are two examples of alternative procedures that have been used to resolve legal claims through processes designed to facilitate settlement by the parties.

\section{Discussion and Conclusions}

A range of choices exist of possible procedures for resolving workplace disputes, with important resulting implications for employment systems. Although these choices have sparked strong debates, consistent dimensions for comparing procedures are often incomplete or lacking entirely. To evaluate the available choices, there is a need for metrics for comparing dispute resolution procedures that go beyond the limited and perhaps flawed dimensions of speed and satisfaction that are so prevalent in the literature. As such, we argue that the objectives of efficiency, equity, and voice provide rich metrics for evaluating and comparing workplace dispute resolution procedures. In the analysis presented here, we have shown how efficiency, equity and voice can be used to compare unionized and nonunion workplace procedures, as well as employment law procedures. Translating our analyses to the triangular framework introduced above yields the locations in the geometry of dispute resolutions procedures shown in Figure 2. 
The usefulness of the diagrammatic triangular approach is in providing an easily accessible platform for comparing different systems.

Unionized grievance arbitration has a relatively strong provision of voice and especially equity, but cost, speed, and flexibility issues reduce its efficiency. In comparison, expedited arbitration performs better on the efficiency dimension because of reduced costs and increased speed, but at the expense of a degree of equity and voice. The inclusion of a pre-arbitration mediation step improves efficiency with only minor trade-offs with equity and voice. In comparison to union procedures, nonunion grievance procedures tend to score higher on efficiency and lower on equity and voice. The favoring of efficiency is seen most strongly in open door policies that provide little protection of equity or voice. Other nonunion options involving management appeal, peer review, and ombudspersons each represent an attempt to provide greater equity and voice. In comparison, the U.S. employment litigation system has greater elements of equity and voice, but is evaluated less favorably in terms of efficiency. Employment law arbitration and mediation schemes can usefully be seen as altering the relative mix of efficiency, equity, and voice.

Our analyses focus on understanding and comparing workplace dispute resolution procedures, but the framework developed here can also be used to design desired procedures. For example, pluralist industrial relations thought emphasizes balancing competing interests (Budd, Gomez, and Meltz 2004). Figure 2 and the accompanying comparative analyses can be used by policymakers to promote specific workplace dispute resolution procedures that balance efficiency, equity, and voice. Other normative frameworks could similarly use these analyses to design procedures that fulfill other desired mixes between efficiency, equity, and voice. In fact, the trajectory of the development of major dispute resolution options within the union, nonunion, 
and employment law arenas largely reflect a struggle among practitioners to find their desired relative levels of efficiency, equity, and voice. For unionized procedures, expedited arbitration and grievance mediation represent efforts to remedy limitations in efficiency in grievance arbitration. The development of peer review and ombudsperson procedures represent efforts to remedy the lack of equity and voice in open door or management appeal procedures. Amongst employment law procedures, both employment mediation and arbitration represent efforts to shift the balance relative to litigation, which strongly emphasizes equity and voice over efficiency.

Even if one disagrees with the specific analyses herein, such debates underscore the need for metrics and illustrates the utility of the efficiency, equity, and voice framework for analyzing and designing dispute resolutions procedures - in and out of the workplace. The challenge for future research is measuring and implementing this rich framework. 


\section{Notes}

${ }^{1}$ Rights disputes are disagreements over whether someone's rights have been violated—rights granted through an employee handbook, a union contract, or an employment law. Such disputes should not be confused with disputes over conflicts of interest such as higher wages (the employees' interest) versus lower labor costs (the employer's interest).

${ }^{2}$ In Budd's (2004) analysis, efficiency is primarily an employer concern while equity and voice are largely employee interests. As applied to dispute resolution, however, these associations are not as strong. For example, efficient workplace dispute resolution methods that yield timely and inexpensive settlements serve both employer and employee interests.

${ }^{3}$ A costly dispute resolution procedure such as a strike or lengthy court trial might be efficient if these costs provide incentives for the parties to avoid such disputes. These incentives are important aspects of dispute resolution systems for interest disputes, but are less important for rights disputes.

${ }^{4}$ In none of these applications is the use of the term "geometry" intended to imply mathematical precision; rather, it is intended to capture the comparison of different properties within a threedimensional space.

${ }^{5}$ It should be noted that in all of the nonunion procedures, employers have a high level of voice in that they control how a procedure is structured and have the fullest participation rights. But because of the imbalance between employer and employee voice, we rate these systems as weak on the voice dimension. A union-controlled grievance procedure-such as in the pre-1930s craft union model of grievance arbitration (Stanger 2001) - is similarly rated as weak on the voice dimension because of the imbalance between employer and employee voice. 


\section{References}

Bacharach, Samuel, and Peter Bamberger. 2004. "The Power of Labor to Grieve: The Impact of the Workplace, Labor Market, and Power-Dependence on Employee Grievance Filing." Industrial and Labor Relations Review 57(4):518-539.

Bemmels, Brian. 1994. "The Determinants of Grievance Initiation." Industrial and Labor Relations Review 47(2): 285-301.

Bemmels, Brian. 1995. "Shop Stewards' Satisfaction with Grievance Procedures." Industrial Relations 34(4): 578-592.

Bemmels, Brian, and Janice R. Foley. 1996. "Grievance Procedure Research: A Review and Theoretical Recommendations." Journal of Management 22(3): 359-384.

Bemmels, Brian, and Dora C. Lau. 2001. "Local Union Leaders' Satisfaction with Grievance Procedures." Journal of Labor Research 22(3): 653-667.

Bingham, Lisa B. 1997. "Employment Arbitration: The Repeat Player Effect." Employee Rights and Employment Policy Journal 1: 189-220.

Bingham, Lisa B. 2004. "Employment Dispute Resolution: The Case for Mediation." Conflict Resolution Quarterly 22(1-2): 145-174.

Bingham, Lisa B., and Debra J. Mesch 2000. "Decision-Making in Employment and Labor Arbitration." Industrial Relations 39(4): 671-694.

Boswell, Wendy R., and Julie B. Olson-Buchanan. 2004. "Experiencing Mistreatment at Work: The Role of Grievance Filing, Nature of Mistreatment, and Employee Withdrawal." Academy of Management Journal 47(1): 129-139.

Budd, John W. 2004. Employment with a Human Face: Balancing Efficiency, Equity, and Voice. Ithaca, NY: ILR Press.

Budd, John W., Rafael Gomez, and Noah M. Meltz. 2004. "Why a Balance is Best: The Pluralist Industrial Relations Paradigm of Balancing Competing Interests." In Bruce E. Kaufman (ed.), Theoretical Perspectives on Work and the Employment Relationship. Champaign, IL: Industrial Relations Research Association, pp. 195-227.

Clark, Paul F., and Daniel G. Gallagher. 1988. "Membership Perceptions of the Value and Effect of Grievance Procedures." Proceedings of the Fortieth Annual Meeting. Madison, WI: Industrial Relations Research Association, pp. 406-414.

Colvin, Alexander J.S. 2001. "The Relationship between Employment Arbitration and Workplace Dispute Resolution.” Ohio State Journal on Dispute Resolution 16(3): 643668. 
Colvin, Alexander J.S. 2003a. "Institutional Pressures, Human Resource Strategies, and the Rise of Nonunion Dispute Resolution Procedures." Industrial and Labor Relations Review 56(3): 375-392.

Colvin, Alexander J.S. 2003b. "The Dual Transformation of Workplace Dispute Resolution." Industrial Relations 52(4): 712-735.

Colvin, Alexander J.S. 2004. "Adoption and Use of Dispute Resolution Procedures in the Nonunion Workplace." Advances in Industrial and Labor Relations 13: 71-97.

Colvin, Alexander J.S., Brian Klaas and Douglas Mahony. 2006. "Research on Alternative Dispute Resolution Procedures.” Ch. 4 in David Lewin, (ed.), Contemporary Issues in Employment Relations. Champaign, IL: Labor and Employment Relations Association.

Commission on the Future of Worker-Management Relations. 1994. Report and Recommendations. Washington, DC: U.S. Departments of Labor and Commerce.

Delikat, Michael, and Morris M. Kleiner. 2003. "An Empirical Study of Dispute Resolution Mechanisms: Where Do Plaintiffs Better Vindicate Their Rights." Dispute Resolution Journal 58(4): 56-58.

Eaton, Adrienne E., and Jeffrey H. Keefe. 1999. "Introduction and Overview." In Adrienne E. Eaton and Jeffrey H. Keefe (eds.), Employment Dispute Resolution and Worker Rights in the Changing Workplace. Champaign, IL: Industrial Relations Research Association, pp. $1-26$.

Edwards, Richard. 1993. Rights at Work: Employment Relations in the Post-Union Era. Washington, D.C.: Brookings Institution.

Eisenberg, Theodore, and Elizabeth Hill. 2003. "Employment Arbitration and Litigation." Dispute Resolution Journal 58(4): 44-55.

Estreicher, Samuel. 2001. "Saturns for Rickshaws: The Stakes in the Debate over Pre-Dispute Employment Arbitration Agreements." Ohio State Journal on Dispute Resolution 16(3): 559-570.

Feuille, Peter. 1999. “Grievance Mediation.” In Adrienne E. Eaton and Jeffrey H. Keefe (eds.), Employment Dispute Resolution and Worker Rights in the Changing Workplace. Champaign, IL: Industrial Relations Research Association, pp. 187-217.

Feuille, Peter, and Denise R. Chachere. 1995. "Looking Fair or Being Fair: Remedial Voice Procedures in Nonunion Workplaces.” Journal of Management 21(1): 27-42.

Feuille, Peter, and John T. Delaney. 1992. “The Individual Pursuit of Organizational Justice: Grievance Procedures in Nonunion Workplaces." Research in Personnel and Human Resources Management 10: 187-232. 
Fryxell, Gerald E., and Michael E. Gordon. 1989. "Workplace Justice and Job Satisfaction as Predictors of Satisfaction with Union and Management." Academy of Management Journal 32(4): 851-866.

Gordon, Michael E., and Roger L. Bowlby. 1988. "Propositions about Grievance Settlements: Finally, Consultation with Grievants." Personnel Psychology 41(1): 107-123.

Hill, Elizabeth. 2003. "Due Process at Low Cost: An Empirical Study of Employment Arbitration Under the Auspices of the American Arbitration Association." Ohio State Journal on Dispute Resolution 18(3): 777-827.

Hyman, Richard. 2001. Understanding European Trade Unionism: Between Market, Class and Society. London: Sage.

Karambayya, Rekha, and Jeanne M. Brett. 1989. "Managers Handling Disputes: Third-Party Roles and Perceptions of Fairness." Academy of Management Journal 32(4): 687-704.

Katz, Harry. C., Thomas A. Kochan, and Kenneth R. Gobeille. 1983. "Industrial Relations Performance, Economic Performance, and QWL Programs: An Interplant Analysis.” Industrial and Labor Relations Review 37(1): 3-17.

Klaas, Brian S. 1989. "Determinants of Grievance Activity and the Grievance System's Impact on Employee Behavior: An Integrative Perspective." Academy of Management Review 14(3): 445-458.

Klaas, Brian S, Douglas Mahony and Hoyt N. Wheeler. 2006. "Decision-Making About Workplace Disputes: A Policy-Capturing Study of Employment Arbitrators, Labor Arbitrators and Jurors." Industrial Relations 45(1): 68-95.

Klare, Karl. E. 1988. "Workplace Democracy and Market Reconstruction: An Agenda for Legal Reform.” Catholic University Law Review 38(1): 1-68.

Kleiner, Morris M, Gerald Nickelsburg, and Adam Pilarski. 1995. "Monitoring, Grievances, and Plant Performance.” Industrial Relations 34(2): 169-189.

Lewin, David. 1999. "Theoretical and Empirical Research on the Grievance Procedure and Arbitration: A Critical Review." In Adrienne E. Eaton and Jeffrey H. Keefe (eds.), Employment Dispute Resolution and Worker Rights in the Changing Workplace. Champaign, IL: Industrial Relations Research Association, pp. 137-186.

Lewin, David. 2005. "Unionism and Employment Conflict Resolution: Rethinking Collective Voice and Its Consequences.” Journal of Labor Research 26(2): 209-239.

Lewin, David, and Richard B. Peterson. 1988. The Modern Grievance Procedure in the United States. New York: Quorum. 
Lewin, David, and Richard B. Peterson. 1999. "Behavioral Outcomes of Grievance Activity." Industrial Relations 38(4): 554-576.

Lipsky, David B., Ronald L. Seeber, and Richard D. Fincher. 2003. Emerging Systems for Managing Workplace Conflict. San Francisco, CA: Jossey-Bass.

McCabe, Douglas M., and David Lewin. 1992. "Employee Voice: A Human Resource Management Perspective." California Management Review 34(3): 112-123.

Meyer, David, and William Cooke. 1988. "Economic and Political Factors in Formal Grievance Resolution.” Industrial Relations 27(3): 318-335.

Olson, Walter K. 1997. The Excuse Factory: How Employment Law is Paralyzing the American Workplace. New York: Free Press.

Olson-Buchanan, Julie, and Wendy R. Boswell. 2007. "Organizational Dispute Resolution Systems." In Carsten K.W. De Dreu and Michele J. Gelfand (eds.), The Psychology of Conflict and Conflict Management in Organizations. New York: Erlbaum.

Ponak, Allen, Wilfred Zerbe, Sarah Rose, and Corliss Olson. 1996. "Using Event History Analysis to Model Delay in Grievance Arbitration." Industrial and Labor Relations Review 50(1): 105-121.

Reuben, Richard C. 2005. "Democracy and Dispute Resolution: Systems Design and the New Workplace." Harvard Negotiation Law Review 10: 11-68.

Stanger, Howard R. 2001. "The Evolution of an Alternative Grievance Procedure: The Columbus Typographical Union No. 5, 1859-1959." Advances in Industrial and Labor Relations 10: 75-113.

Stone, Katherine V.W. 1981. "The Post-War Paradigm in American Labor Law." Yale Law Journal 90(7): 1509-1580.

Stone, Katherine V.W. 1996. "Mandatory Arbitration of Individual Employment Rights: The Yellow Dog Contract of the 1990s." Denver University Law Review 73: 1017-1050.

Wheeler, Hoyt N., Brian S. Klaas, and Douglas M. Mahony. 2004. Workplace Justice Without Unions. Kalamazoo, MI: W.E. Upjohn Institute for Employment Research.

Zack, Arnold M., and John T. Dunlop. 1997. Mediation and Arbitration of Employment Disputes. San Francisco: Jossey-Bass. 
Table 1. Three Metrics for Dispute Resolution

Dimension/Definition

Efficiency

Effective use of scarce resources

Equity

Fairness and justice

Voice

Ability to participate and affect decision-making
Dispute Resolution Concerns

Cost

Speed

Promotion of productive employment
Unbiased decision-making

Effective remedies

Consistency

Reliance on evidence

Opportunities for appeal

Protections against reprisal
Hearings

Obtaining and presenting evidence

Representation by advocates and use of experts

Input into design and operation of a dispute

resolution system

Participation in determining the outcome 
Figure 1. The Geometry of Dispute Resolution

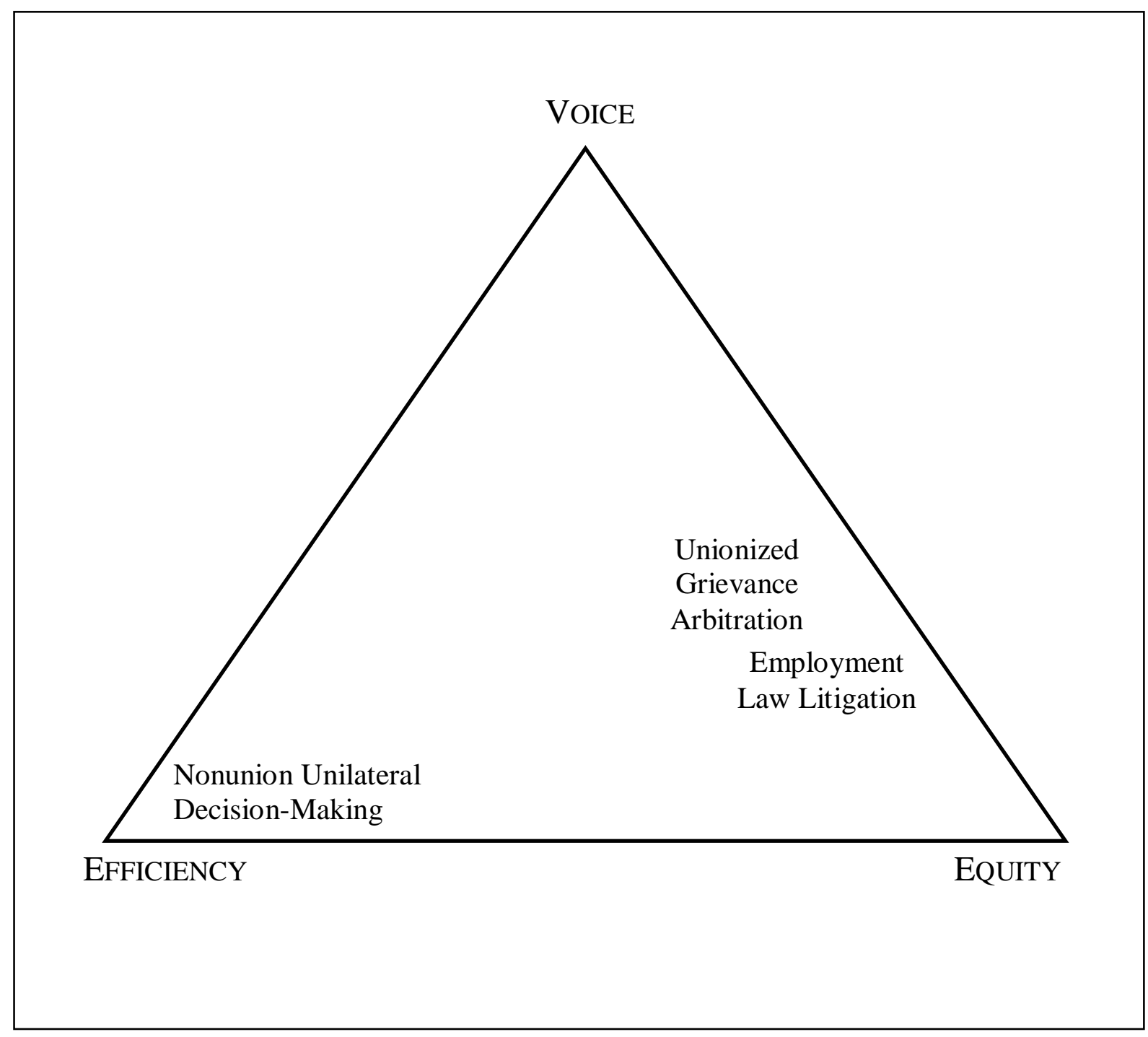


Figure 2. The Geometry of Dispute Resolution: Putting It All Together

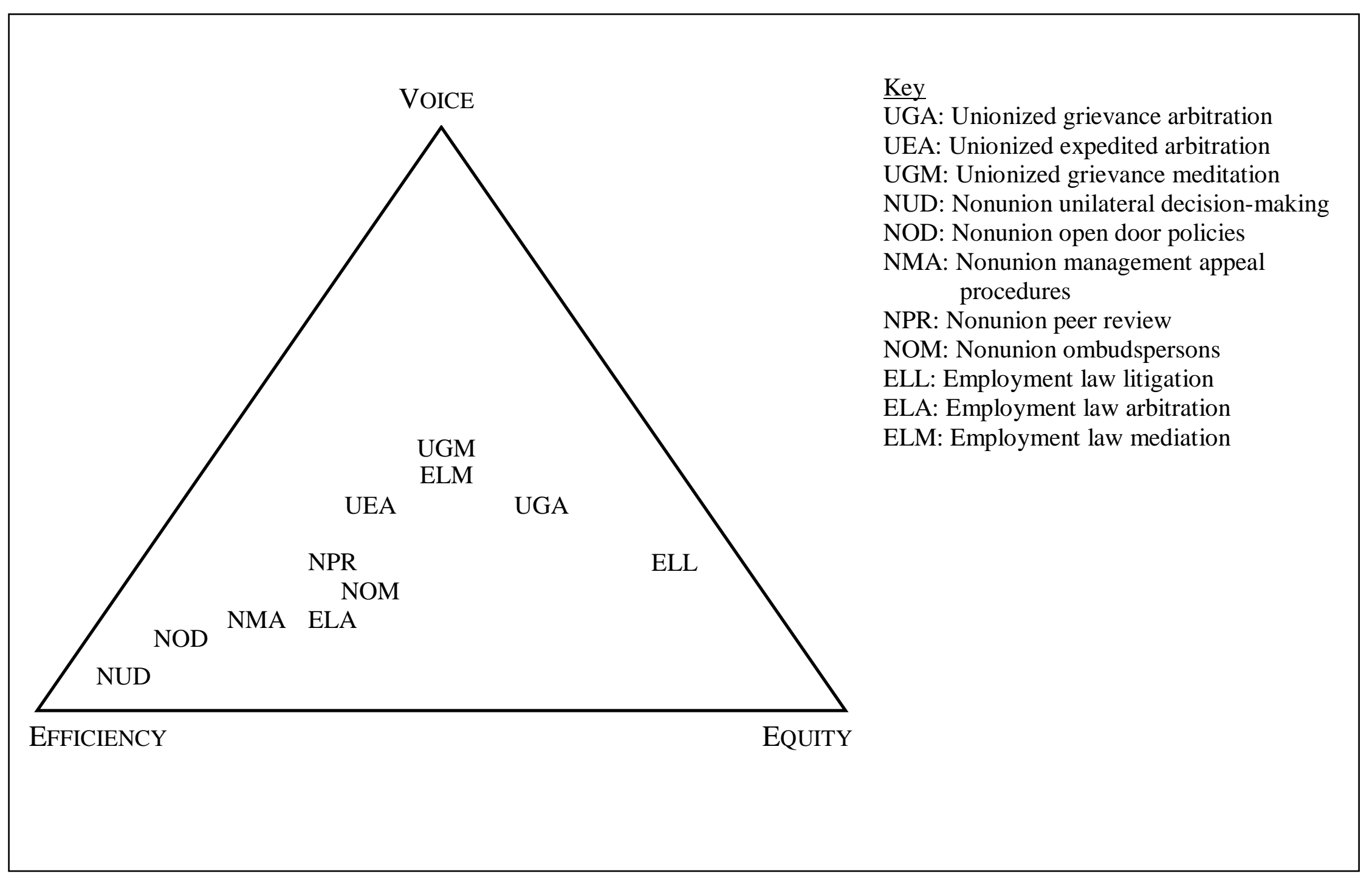

